Review

\title{
Realism, skill, and incentives: Current and future trends in investment management and investment performance
}

\author{
Andrew Mason ${ }^{\mathrm{a}, 1}$, Sam Agyei-Ampomah ${ }^{\mathrm{b}, 2}$, Frank Skinner ${ }^{\mathrm{c}, *}$ \\ a Surrey Business School, University of Surrey, Surrey GU2 7XH, The United Kingdom \\ b Ghana Institute of Management and Public Administration, P O Box AH 50, Achimota, Accra, Ghana \\ c Brunel University London, Uxbridge UB8 3PH, The United Kingdom
}

\section{A R T I C L E I N F O}

\section{Article history:}

Received 18 May 2015

Accepted 11 October 2015

Available online 25 October 2015

\section{JEL classification:}

G1

G23

Keywords:

Investment management

Investment performance

Mutual funds

Factor models

Skill

Characteristics

Incentives

\begin{abstract}
A B S T R A C T
We review the recent trends in investment management and performance research and highlight the fields expected to develop further in the future. The trend to adapt the classic CAPM and factor models seems likely to continue, with the drive for realistic factors, which best proxy the drivers of investment performance, playing a key role. The search for skill, based on enhanced benchmarks, is also a developing area, with new concepts of identification and verification at the fore. The availability of more qualitative data has allowed corporate finance themes such as agency conflict and incentives to be explored. These are some of the areas where we have seen major developments in recent years and where we expect to see continuing development.
\end{abstract}

(c) 2015 The Authors. Published by Elsevier Inc. This is an open access article under the CC BY-NC-ND license (http://creativecommons.org/licenses/by-nc-nd/4.0/).

\section{Contents}

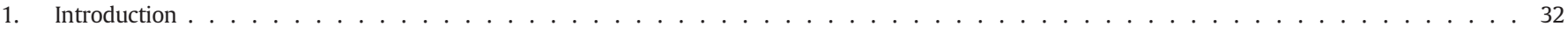

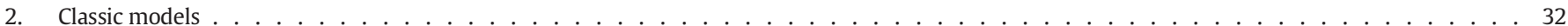

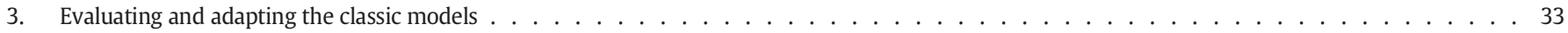

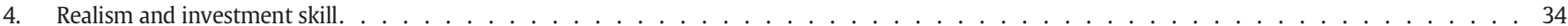

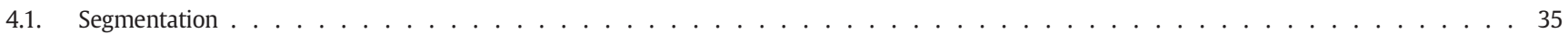

4.2. Skill $\ldots \ldots \ldots \ldots$

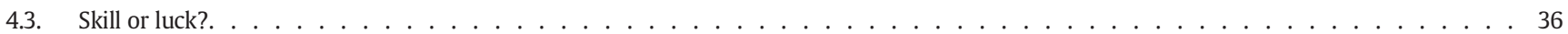

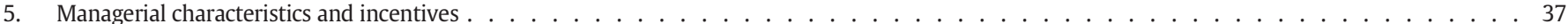

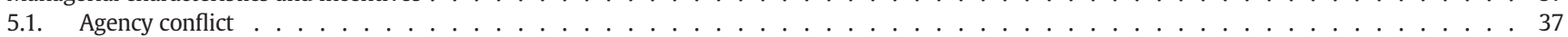

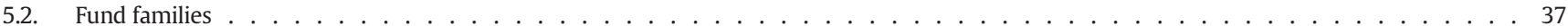

5.3. Incentives . . . . . . . . . . . . . . . . . . . . . . . . . . . . . . . . . . . . . .

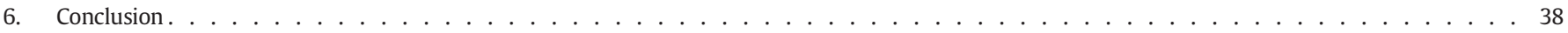

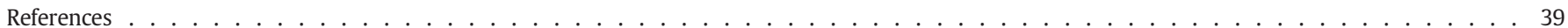

\footnotetext{
* Corresponding author. Tel.: +441895 267948.

E-mail addresses: andrew.mason@surrey.ac.uk (A. Mason), sagyei-ampomah@gimpa.edu.gh (S. Agyei-Ampomah), frank.skinner@brunel.ac.uk (F. Skinner).

1 Tel.: $+441483683,093$
}

2 Tel.: $+233302,401,681$. 


\section{Introduction}

Investment consultants and academic researchers alike are interested in issues related to investment management and investment performance. Accordingly, the aim of this paper is to review the existing methods of investigating investment management and performance, to comment on current trends and to extrapolate forward areas of investigation which are likely to expand. The classic theories are well known and covered in this paper for the sake of completeness, but the focus of the paper is on developments in the recent decade, of which there are many, and future areas which we consider to be likely areas of investigation.

In this study, we look at the classic and historical theories and major empirical studies of investment performance including the Capital Asset Pricing Model (CAPM) of Sharpe $(1964,1967)$ and Jensen's $(1968)$ and multifactor models such as those of Fama and French $(1992,1993)$ and Carhart (1997) (Section 1). While these models still play an active part in current academic research, they have not met the requirements of the investment industry so the need for investment benchmarks remains in order to satisfy the continuing need to measure investment performance.

It can be observed that the range of views on the efficacy of such models is wide indeed (Section 2). At one extreme, we have those who broadly accept the assumptions and findings of classic models such as Fama and French $(1992,1993)$ and use them as a jumping off stage for extension. At the other extreme, we observe those who believe that the biases and artificial constructs of these models have no role to play in the assessment of management performance as they set out to measure something neither investors nor investment managers attend to in the business world. The reluctance of the investment industry to accept the traditional factor models naturally leads us to enquire why they have not been adopted and what would a more acceptable alternative of measuring investment performance entail? We consider the refinements to these models and the reasons given why they have not been adopted. This leads naturally towards refinements in classic benchmarks, where the models bear more resemblance to the benchmark for a style of investment or a category of funds that are actually in use and reflects the constraints fund managers must operate within. ${ }^{3}$ These models often bear more resemblance to the CAPM and the singlefactor models, but with a selected benchmark to represent the appropriate investment universe thus aligning them more closely with investment practise where a combination of investment benchmark and investment peer group form the basis of monitoring. ${ }^{4}$ Such alignment is not completely out of step with the multifactor models developed by Fama and French (1993). Connor (1995), writing shortly after Fama and French (1993) termed such models fundamental factor models. Such models rely on empirical findings with respect to stock characteristics such as size or book-to-market ratio. More recent studies investigate whether such effects can be captured by models using a single benchmark which more closely aligns itself with those funds it is benchmarking.

If an appropriate benchmark can be identified, this leads to the assessment of investment skill or manager value-added (Section 3). If there is skill, what type of skill is there, how do we capture this, and

\footnotetext{
${ }^{3}$ We should highlight some of the desirable elements of a benchmark before entering into in depth discussion of the strength or weakness of particular approaches. A benchmark should provide a 'Naïve' representation of the set of investment opportunities facing investors. The index should be investible and cover the practical opportunities for an investment style. It should be float-adjusted i.e. it should be based on the market capitalisation of tradable shares. Perhaps more importantly, openness, clarity and simplicity are welcomed as indexes which are transparent in their methodology can be replicated by others. The most important area in which the multi-factor models have failed is in the crucial area of 'intuitive believability' in other words a benchmark should be based on rules that are accepted by the investment community; mutual funds and their investors.

${ }^{4}$ An appropriate benchmark will reflect the risk-reward parameters of the investable universe by a fund or group of funds. A 'Total Market' benchmark is often not appropriate because of the mandate of a fund and the restrictions within a fund prospectus.
}

does it cover manager fees? Recently, however, investigations have gone beyond this and now attempt to answer the question, if there is excess performance, is this due to skill or luck? The greatest share of the money invested in equity mutual funds is still invested in active management. The U.S. mutual fund industry has assets of \$15 trillion, approximately $50 \%$ of total world mutual fund assets (Investment Company Institute, 2014). U.S. Domestic Equity funds comprised 38\% of this $\$ 15$ trillion. Despite the rapid growth of index funds and significant redemptions, actively managed funds still account for $82 \%$ of U.S. equity funds. This suggests that a greater proportion of investors believe that investment managers have the skills to outpace the market. Are the majority of investors misinformed and approximately $\$ 2.4$ trillion are misallocated or might we be missing something? Do they have motives or incentives that we do not understand? We thus expect the search for more appropriate benchmarks and improved identification and assessment of skill to continue to expand in the foreseeable future. If theories and models of investment are not accepted or implemented by investors and the investment industry, it is difficult to envisage what economic impact new benchmarks and assessments of skill can have.

The increasing availability of qualitative data and the developments in the ability to process this has allowed investment research to incorporate research on managerial characteristics and incentives (Section 4). This allows us to consider agency conflict within the fund management industry and incentives that may influence the activities of fund families and fund managers. This is an area of investment research which can only increase as more data become available and interest expands beyond the purely quantitative assessment of investment.

The remainder of the paper is organised as follows: Section 1 covers the classic and historical theories and major empirical studies, including the standard multifactor models. Section 2 looks at evaluating and adapting the classic models. Section 3 considers realism in benchmarking and investment skill. Section 4 reviews the impact of managerial characteristics and incentives. The final section concludes and contains our views on which areas of research seem destined to grow as techniques improve and data becomes available.

\section{Classic models}

The traditional models which have dominated the study of investment management and investment performance are anchored in the concepts of the Capital Asset Pricing Model of Sharpe (1964) and Jensen (1968) where both authors focus on the performance of mutual funds and the value added by managers to the performance of a passive index representing an investible universe. Almost 50 years later, the concepts introduced within these ground-breaking papers are still the core means of investigating investment value added even though the means of evaluation have been greatly extended. Groundbreaking work was also introduced by King (1966) and Farrell (1974) who established that stock price behaviour may be due to latent or common factors. The next phase of major innovation came in the 1990s when Fama and French $(1992,1993)$ introduced a set of risk factors which proxies the effects of the market, stock size, and stock valuation on performance and Carhart (1997) extended the model by the addition of stock price momentum. ${ }^{5}$ Thus, the bedrock of academic investigation of investment performance was established via the CAPM model and the three-factor (Fama \& French, 1992, 1993) and four factor Carhart (1997) models. These models are still widely used today in their original form but have also been modified, with many variants now in existence.

Driven by pension reform, the 1990s also saw the explosive growth of the mutual fund sector and a search for an adequate means of

\footnotetext{
${ }^{5}$ It should be noted that the factors presented by Fama and French (1993) represented styles and strategies of investment that had been known for many years (See for example Graham, Dodd, and Cottle (1934) or Fisher (1958).)
} 
benchmarking and performance measurement; see Grinblatt and Titman (1992) and Goetzmann and Ibbotson (1994). Sharpe (1992) also turned his attention again to investment performance and established a returns-based model of style analysis (RBSA) based on estimated exposure to a set of passive indexes. On the basis of this work, Sharpe also collaborated with index providers to develop style benchmarks reflecting differing investment universes while BARRA was established based on the risk factors identified by Farquhar, Rosenberg, and Rudd (1982). ${ }^{6}$ Another key development in the consideration of investment performance and the factors affecting it is the work of Ferson and associated authors who sought to incorporate factors reflecting the economy and the stage of the economic cycle to 'condition' performance measurement; see Ferson and Schadt (1996). The investigation of mutual fund style by Brown and Goetzmann (1997) concludes that narrow categorisation of investment styles is not capturing the diversity of investment approaches employed in the market. The market for investment funds is a segmented market, differentiated by size and investment style. Daniel, Grinblatt, Titman, and Wermers (1997) outline the problem that the classic factor models typically used in performance studies may be unable to identify any abnormal or value-added performance if a fund's style characteristics differ markedly from its benchmark. They address some of these concerns by constructing passive characteristics-based benchmarks utilising size, price to book, and the lagged returns of actual portfolio holdings. This is a key issue taken up in Section 3, where the appropriate choice of investment benchmarks is considered in detail.

To sum up the classic investment models, they seek to establish a benchmark to judge and classify investment performance as, good, bad, or indifferent as a guide to investment selection. Despite their limitations, these classic theories or models still play an important role in academic research, in some cases, as a jumping-off point for further extension, but in other cases, as a set of ill-judged constructs to be disproved and dismissed.

The focus of this paper is, however, on the developments which have taken place in recent years and identification of emerging trends in research so we will move on while observing that reviews of the earlier periods may be found in Cuthbertson, Nitzsche, and O'Sullivan (2010), Mason (2013), or Ferson (2013).

\section{Evaluating and adapting the classic models}

This section considers the attempts to improve upon and extend the classic models or to evaluate classic models and suggest alternative approaches. As we will see, views on the usefulness of the traditional factor models are extremely diverse. The analysis we note and the findings of biases and shortcomings of the classic models of investment performance sowed the seeds for the move towards improving benchmarking via the move towards appropriate benchmarking in investment performance evaluation that we cover later in this review.

Most of the literature focuses on extending the three-factor model rather than refining the Jensen (1968) CAPM model as multifactor models are themselves an extension of the CAPM model. Typical of the adaptions of the three- and four-factor models is the study by Wagner and Winter (2013), who extend the Fama and French (1992) and Carhart (1997) factor models by adding two new factors representing liquidity and idiosyncratic risk to form a six-factor model. Others have factored economic elements into their models such as Stivers and Sun (2010), who utilise the classic four-factor model in their study on the cross-sectional dispersion in stock returns under varying economic conditions. They conclude that the value premium, Fama French's (HML), is countercyclical while the momentum premium (MOM) is procyclical. This conclusion is consistent with practitioner observations. Value stocks (HML) are often seen as defensive

\footnotetext{
${ }^{6}$ BARRA provides a suite of analytical tools for portfolio managers and is now part of MSCI as MSCI BARRA. http://www.msci.com/products/portfolio_management_analytics/
}

and are favoured in a downturn in the stock market as typically they have a low price/book ratio and a high dividend yield while momentum-driven stocks (MOM) tend to have high price/book ratios, low dividend yields, and high growth rates.

Early market-timing models of Treynor and Mazuy (1966) and Henriksson and Merton (1981) are often used in conjunction with factor models to assess the performance of investment funds. These market-timing models are updated by Elton, Gruber, and Blake (2012). One of their insights is that earlier models merely assume that market timing took place in a prescribed or formalised manner. Their study, which incorporate monthly portfolio holdings and 'bottom-up beta' calculations, highlights the fact that managers can adjust their market exposure by increasing or decreasing their exposure to particular sectors or stocks with different market exposures such as high beta, small caps, or technology stocks. Such insights reflect strategies employed by mutual fund managers who have to be fully invested in the segment of the market they specialise in but may choose to alter their market risk via stock or sector selection.

Goetzmann, Ingersoll, Spiegel, and Welch (2007) turn their attention to the possible 'gaming' of a wide range of performance measures including the Sharpe ratio (1967) and Jensen's (1968) alpha and propose what they term the Manipulation-Proof Performance Measure (MPPM). They suggest that the MPPM can overcome the shortcomings of a wide range of performance models where fund managers can radically alter the return distribution by using derivatives or dynamic trading strategies. Brown, Kang, In, and Lee (2010) develop the 'Doubt Ratio' (DR), a diagnostic statistic derived from the MPPM which indicates whether the reported returns from funds are suspicious. The MPPM and the DR appear more applicable to hedge funds because mutual funds reporting requirements may prohibit what they call 'information-free investing'.

We now turn to studies evaluating the classic investment performance models finding a catalogue of shortcomings or biases which tend to suggest that the abstractions of those models need to be overcome to have a meaningful impact on investment practice.

In a key study, Chan, Dimmock, and Lakonishok (2009) address the salient issues affecting the benchmarking of investment managers' performance. They conduct a detailed study of the main methods used in academic studies and investment practice, including regressionbased benchmarks such as the Fama and French (1993) three-factor model, and characteristics-based benchmarks such as the Russell indices. They warn that it is important to identify a manager's style or fund manager's investment beliefs i.e. where anomalies may lie in the market or which stock characteristics may yield the most fruitful investments. Once this is established, they should select a benchmark which represents as closely as possible the investment opportunity set of the fund, thus mimicking the underlying strategy of the portfolio. This allows greater confidence in any assessment of skill. They note that even when methodologies are based on the same premise, for example, size and market to book, results can be surprisingly different. They find that characteristics-based benchmarks such as the Russell Indexes track actual portfolios more closely than regression based models. Their key finding is that investment performance is so sensitive to benchmarking methodology that there is not only disagreement about the size of abnormal returns, there is also disagreement about sign in some cases. ${ }^{7}$ The findings of Chan et al. (2009) fuel the investigation into style-appropriate benchmarks and the endeavour to reflect a funds true investment

\footnotetext{
${ }^{7}$ Chan et al. (2009) warn about complacency about the interchangeable nature of the proliferation of variants of value-growth and size benchmarks or attributes and also the differences that can be produced by different processes. While superficial consideration may lead to an assumption that cross-sectional regression of benchmarks and timeseries benchmark models will generate very similar outcomes for abnormal returns that is not the case. In their sample of mutual funds for the period 1989-2001 they found that the various different benchmarks they applied disagree on the sign (over or underperformance) in approximately a quarter of cases!
} 
universe and constraints when evaluating investment performance (see Section 3 Realism and Investment Skill).

Huij and Verbeek (2009) find that the standard multifactor models have biases which overstate/understate mutual fund performance as the hypothetical stock portfolios do not incorporate transaction costs and the impact of fund restrictions on trading. While the problem may be insignificant for the CAPM model, the biases are economically significant for the multifactor models. Their results confirm the existence of a value premium (Fama \& French, $1993 \mathrm{HML}$ ) and a momentum premium (Carhart (1997) winner minus loser (WML)) but find no evidence of a small cap premium (Fama \& French, 1993 SMB). They find that alphas for value funds have a systematic downward bias and those for growth funds have a systematic upward bias. They conclude that investment performance evaluation would be best achieved through the utilisation of factors based on fund returns rather than stock returns.

Ferson and Lin (2014) consider the issue of investor heterogeneity and argue that traditional alphas are not a sufficiently good indicator of whether a fund is an attractive investment or not and extend the traditional multifactor models by incorporating an investor's utility function. Their model sets boundaries for investor disagreement and diversity, which are found to be both economically and statistically significant. One of the implicit assumptions of earlier models is that investors behave as if they are homogenous which given the many types of agents operating in financial markets is clearly a heroic assumption.

Bali, Brown, and Caglayan (2014) propose proxies for economic uncertainty as new measures of macroeconomic risk. They find that while their uncertainty betas explain a significant proportion of the crosssectional variation in hedge fund returns, they do not report economically significant results for mutual funds. This reinforces the view that it is important to consider the restrictions facing mutual funds as emphasised by Cremers, Petajisto, and Zitzewitz (2012).

It should be noted that while knowledge of the traditional factor models has been widely disseminated over the past decades, by and large, they have not been adopted by the investment industry. In contrast, the BARRA risk models have been commercialised and are widely used in the investment industry. It is also pertinent that industry benchmark providers have all moved from the simple sorts implied by the traditional factor models to more advanced methods of assessing growth-value orientation. Over the last decade, all of the major index providers, Standard \& Poor's/Citigroup, Russell, MSCI and Dow Jones Wilshire, ${ }^{8}$ have realised that simple rankings by a single valuation multiple such as Price to Book or Price to Earnings does not adequately reflect investment styles or provide an adequate means of providing benchmarking for investors that have a defined investment style. Thus, in addition to providing an array of size breakpoints which include large-cap, mid-cap, and small cap, they also provide more focussed indices. They have all moved towards methods of index calculation which reflect the growth-value orientation of the underlying shares.

A late entrant to the improvement of Fama and French (1993) comes from Fama and French (2015) who move from a size- and valuationbased model to four- and five-factor models which improve upon their classic three-factor model. The new factors are a profitability factor (Robust minus Weak RMW) and an investment factor (Conservative minus Aggressive CMA). RMW is based on operating profit and is defined as the difference between returns on portfolios with robust and weak profitability. CMA is the difference between the returns of low investment firms (conservative) and high investment firms (aggressive) based on the growth rate of total assets. The profitability factor may be regarded as a growth factor, whereas their traditional Book to Market factor is a valuation measure. Their results show that a four-factor model comprising market returns, size, profitability, and investment captures all or more than a five-factor model which includes

\footnotetext{
8 There have also been realignments and mergers within the index providers, thus S\&P and Citigroup are now combined, Barra has been incorporated into MSCI and Dow Jones and Wilshire are also now a single entity.
}

valuation. They also compare both models with their traditional threefactor model updated with 21 years of extra data. Their study period runs from July 1963 to December 2013. Having tested the various models over this prolonged period, they suggest that the valuation factor $(\mathrm{HML})^{9}$ is redundant because the effect of that factor is fully captured by the other factors, particularly profitability and investment. They do, however, include it in the five-factor model to facilitate capture of the 'value premium'.

While these studies are prominent, they are only the tip of the iceberg when we consider the suitability of a benchmark as a yardstick for investment. This leads us to the ongoing development of realism in benchmarking and more advanced methods to probe whether investment skill truly exists. Before moving on, we should reflect on the observation of Chan et al. (2009) that a model which does not mimic a fund's investment universe is of little value as an indicator of skill.

\section{Realism and investment skill}

The increasing trend towards realistic assessment of the constraints facing investment managers and the drive for appropriate benchmarks are two important themes in recent years which are set to continue in future research. The theme of appropriate measures of skill is also developed further in a series of papers, including Kosowski, Timmermann, Wermers, and White (2006) and Fama and French (2010). They raise the question that if abnormal returns or alpha exists, is this due to luck or skill? This drive towards better identification of skill also seems likely to continue to be a key element of future research on investment outcomes and appraisal.

The acknowledgement of market segmentation is a key development in the analysis of investment performance and investment flows. Typically, the markets are segmented by size and investment style. Size is the market capitalisation of the stocks invested in by a fund while style is slightly more complex. Style reflects a fund or fund manager's investment philosophy or investment beliefs, i.e., where anomalies lie in the market or which stock characteristics may yield the most fruitful investments. The investment process then filters stocks to reflect these characteristics and a portfolio is generated with biases which reflect these characteristics. This is widely accepted in a segmented market such as the U.S. equity market where peer groups are formed on this basis for comparison, and appropriate benchmarks are selected which reflect the different investible universes of such funds.

Wahal and Yavuz (2013) highlight the fact that while style investing is ubiquitous among investors, from retail to institutional investors, investment consultants and pension plan sponsors, it has attracted little attention in academia. A few exceptions, including Barberis and Shleifer (2003), focus on this important area introducing the concept of differentiated groups of funds offering fundamentally different sets of risk return opportunities into the assessment of investment performance and skill. They outline conditions that must be met for a style classification scheme. Styles must be widely followed by investors. In total, they must span their asset class and membership must be mutually exclusive. Their results suggest that style investment, and it's generation of co-movement among similar stocks, plays a significant role in the predictability of asset returns.

The theme of investor differentiation and its impact on investment is developed by Menzly and Ozbas (2010). They highlight the nature of market segmentation and information flows, relaxing the assumptions of the efficient market hypothesis and introducing a degree of friction into asset price adjustments by highlighting the delayed price response to shocks in related firms. They assert that investor specialisation has a significant effect on price formation as this specialisation results in informational segmentation of markets and is consistent with the trading behaviour of informed investors. Schultz (2010), following Grossman

\footnotetext{
${ }^{9}$ HML is High Book to market Minus Low book to market returns. This is said to capture the 'value' premium.
} 
and Stiglitz (1980), focuses on the arguments that markets should be inefficient enough to reward analysts or investors for the cost of their analysis. Collecting information, arbitrage and trading are both costly and risky, therefore markets might be competitive but still informationally inefficient. Given the different levels of difficulty in analysing (or trading) in differing areas of the market, it is logical that the rewards to research and analysis are higher in areas where more time or skill is required. For example, they find that abnormal returns of small growth stocks held by mutual funds were considerably higher than large-cap value stocks, and this was justified by both complexity of analysis and risk.

It seems that the requirements of practitioners and academic studies are becoming more closely aligned as one of the fundamental requirements of a good benchmark is that it should be investible and should reflect the universe of opportunities, with attendant risks, within the constraints imposed on the manager. Kothari and Warner (2001), Cremers et al. (2012), and Angelidis, Giamouridis, and Tessaromatis (2013) all argue that if a benchmark does not reflect the investment style characteristics of the fund being evaluated, it will be unable to determine whether a fund generates any abnormal returns or superior performance. Equity investment styles may be considered as groups of investors who share some common beliefs, whose portfolios share common characteristics, and whose investment portfolios behave similarly under varying conditions. The determination of investment style is a multi-dimensional issue reflecting different combinations of revealed preference for income, growth, and asset backing, as a form of product differentiation. They all indicate that standard multifactor models fail in this respect as they do not reflect the characteristics and objectives of the funds under review. Huij and Verbeek (2009) suggests that in addition to the market factor, funds would need to invest in hedge portfolios which account for the risks in small, growth, and momentum factors if they are to be evaluated against a multifactor benchmark, but due to trading restrictions and very high costs, this is not possible. ${ }^{10}$ Further concern is raised when Chan et al. (2009) noted that different models or benchmarks could evaluate investment performance not only with different values but in some cases with different signs, thus underlining the importance of using an appropriate benchmark. Sensoy (2009) and Goetzmann et al. (2007) argue that benchmarks used by funds should not be subject to gaming and should be well grounded in economic theory. Sensoy (2009) links mismatched self-designated benchmarks, on a growth-value dimension, with fund incentives to increase fund flows. Overuse of the S\&P500 index by funds with a style bias is highlighted.

Cremers et al. (2012) highlight the inherent biases of the Fama and French (1993) and Carhart (1997) three-factor and four-factor models, particularly the treatment of small cap stocks and the market factor. They outline very clearly that a good benchmark should provide 'the most accurate estimate of a portfolio manager's added value relative to a passive strategy' and propose using stock market indices, which are widely accepted and are tradable, as the factors in investment performance evaluation. This follows on from their earlier paper, Cremers and Petajisto (2009), which highlights the importance of identifying the correct benchmark or index to analyse active managers. This is important because using an inappropriate benchmark, which does not reflect a manager's investible universe, leads to misinformation about tracking error and obscures evaluation of performance using tools such as the information ratio. ${ }^{11}$

\footnotetext{
${ }^{10}$ Mutual funds are not benchmarked against multi-factor models; in practise they are benchmarked against stock market indices and peer group rankings.

${ }^{11}$ Chan et al. (2009) define tracking error (tracking error volatility) as the annualised standard deviation of excess returns i.e. the standard deviation of the difference between a fund (or index) return and its benchmark on a periodic basis generally monthly or quarterly. Two conditions necessary for the calculation of tracking error are that the benchmark is a good fit for the portfolio being assessed and that the benchmark has a beta of 1. The information ratio measures the amount of excess return per unit of tracking error (active risk).
}

Angelidis et al. (2013) share some findings with Elton et al. (2012) but have arrived at them from a returns-based perspective rather than an asset holding-based perspective. Angelidis et al. (2013) conclude that it is appropriate to use managers' designated benchmarks rather than the traditional factor models to evaluate investment performance as fund behaviour is determined by the prospectus benchmark which they are in practice evaluated against. The use of inappropriate benchmarks is policed in practice by investment consultants and organisations such as Morningstar and Lipper whose business is to disseminate information on investment funds to their clients. ${ }^{12}$ Like Elton et al. (2012), they find evidence of dynamic factor timing as funds adjust their exposure to size, value-growth, or momentum factors. They observe that traditional models underestimate skill although on average managers do not add value, with stock selection being the biggest culprit causing underperformance.

The concept of active peer benchmarks (APB) which augment the traditional multifactor models is introduced by Hunter, Kandel, Kandel, and Wermers (2014) to evaluate mutual fund performance. They have the advantage of being more closely aligned with investor and industry practice. They observe that Morningstar and Lipper produce similar peer groups but without a formal model. ${ }^{13}$ The reference group for each investment style is thus an equally weighted group of funds following the same strategy, for example, their best-fit index is the same. ${ }^{14}$ One of the advantages of this methodology is that it captures any commonalities in changing bets over time. The authors claim that skill does exist for some funds and the APB benchmark greatly aids the identification of skilled funds.

\subsection{Segmentation}

In a paper, which straddles several of our emerging themes, realism, skill, managerial characteristics, and incentives, Guercio and Reuter (2014) address the question; if active funds underperform the market why is the majority of money invested in actively managed funds? They conclude that the market for funds is segmented and the method by which mutual fund shares are acquired, via a broker or directly from a fund manager, play a significant role in the nature of the funds they invest in. Informed or experienced investors tend to invest and dis-invest directly and this incentivises funds to strive to generate alpha while 'disadvantaged' investors (Gruber, 1996) are either uninformed about performance or have difficulties processing and acting upon this information thus providing funds with less incentive to generate alpha.

While investment fees have attracted much attention in the literature, with frequent comparisons of gross and net alpha, the impact of taxation on investors and the mutual funds they invest in attracts little attention until recently. Sialm and Starks (2012), however, examine the role of tax exempt defined contribution (DC) schemes on mutual funds. They find that pension plan sponsors and pension plan members prefer certain characteristics, namely, larger fund families, higher assets under management, and lower expense ratios. Thus, a higher proportion of DC assets are found in funds possessing those characteristics. Such funds tend to be less tax-efficient in their trading and their realisation of capital gains than funds with a low proportion of DC assets. The authors find, however, that tax-efficient funds do not have any lower risk-adjusted returns than their high proportion DC equivalents.

The recent availability of fund specific data has led to further analysis of the determinants of the flow of funds into and out of mutual funds.

\footnotetext{
12 Where managers have a clearly defined investment, Morningstar, Lipper and investment consultants will compare them to a style appropriate investment benchmark and an appropriate peer group. Specialised funds also tend to compare themselves to a style consistent benchmark but their marketing also tends to compare their performance to the S\&P Composite Index.

13 They may wish to disagree with this view expressed by Hunter et al. (2014).

${ }^{14}$ A best-fit index would be one of a range of indices which when regressed against the returns of a fund had the greatest explanatory power.
} 
One of the most important theoretical papers in this area is Berk and Green (2004), where they develop a 'rational' model embracing past performance and fund flows. They claim their model establishes a relationship between fund flows and performance, which is consistent with high average levels of skill but with a great deal of heterogeneity between managers. This heterogeneity suggests that it is worth pursuing the goal of identifying value-added investment skill. Berk and Green (2004) conclude that managerial skill is a scare resource which dissipates as scale increases. This is consistent with the investment consultants questions noted elsewhere: is performance explainable, repeatable, and scalable? Berk and Green's (2004) equilibrium arguments are widely accepted as they provide theoretical and empirical argument which intuitively explained why investment persistence tails off as a consequence of heavy flows of funds in the wake of superior performance. Glode's (2011) model builds on the findings of Berk and Green (2004) but develops the idea that where active returns vary with the state of the economy, the decision to invest in an actively managed fund is not irrational because a performance measure that does not perfectly specify the pricing kernel of mutual funds will understate the value-added of active management.

Sialm, Starks, and Zhang (2015) shed more insight into the flows of funds through investigating DC Pension funds relative to non-DC related funds holders. A significant proportion of mutual funds are held via DC pension plans, where plan sponsors provide a menu of fund choices for participants of their schemes. ${ }^{15}$ They observe that DC sponsor flows react more to fund performance by adding or removing funds from their menu of offerings in response to fund returns than non-DC holders. The plan sponsors rather than scheme participants effectively determine flows as they move all holdings out of a fund, for example, when they remove it from their menu. This tendency is increasing over time. They suggest regulatory changes, and pressure from employees, including those bringing lawsuits, and public opinion may be behind this trend as plan sponsors are under pressure to perform their fiduciary duties. They comment on the effects of this switching and while it may not predict 'winner' funds, it at least avoids prolonged exposure to the worst performing funds. They conclude that in the long term, such performance chasing behaviour does not harm participants' long-term pension performance prospects.

We can see from the above research that the move towards embracing more specialised factors is widely accepted with authors utilising benchmarks which more accurately reflect the investment universe and investment constraints of funds under review. We believe this trend is set to continue and the more realistic or constrained the benchmark that is used, the more useful any pronouncement of manager skill will be. Evaluating funds against the expectations of their investors should be of more economic benefit to those investors than using benchmarks which are neither used by investment funds or their clients.

\subsection{Skill}

There is much debate over whether active equity investment managers possess skill in the aggregate, although the consensus is that they do not (See Fama and French, 2010, for example). There are, however, mixed messages about whether some managers possess skill or whether skill is found under certain circumstances. By skill. we mean do managers make a value-added contribution to fund performance in a way that cannot be explained by chance. In the best-performing funds, we find value-added or value-creating properties, while in the worst cases, we find value-destroying contributions. Carhart (1997) found little evidence of skill (value-added) and his findings were echoed by others. Berk and Tonks (2007) found that persistence tends to be found among the worst-performing funds (value-destroying).

\footnotetext{
15 DC Funds hold 27\% of U.S. Equity funds assets. Based on Investment Company Institute (2014) figures.
}

This finding was in line with earlier studies such as Goetzmann and Ibbotson (1994), who found persistence among the worst performers, although like Fama and French (2010), they also found evidence of persistent superior performance by the very best funds. Chen, Jegadeesh, and Wermers (2000) and Kosowski et al. (2006) find evidence of superior performance among growth-oriented funds. In addition to the question, do funds possess skill in general, the question is also raised, do funds possess certain types of skill. Baker, Litov, Wachter, and Wurgler (2010) provide evidence of stock-picking skill around earnings announcement time which complements earlier work by Chen et al. (2000) and others who provide some evidence of stock-picking skill, although this skill is neutralised by trading costs and fees. Baker et al. (2010) find that stocks bought prior to earnings announcements outperform those sold by mutual fund managers and conclude that this is in part due to their ability to forecast earnings-related fundamentals.

Kacperczyk, Nieuwerburgh, and Veldkamp (2014) make a significant contribution to the assessment of investment skill in their study of time-varying fund manager skill. They conclude that skilled (successful) managers pick stocks well in booms and time the market well in recessions and deploy their skills differently over the course of a business cycle. This corresponds closely to a practitioner's view of a skilled manager as one who can make abnormal returns in the good times but hold onto them in the bad times. They go further and state that stock picking and market timing are tasks which skilled managers can perform effectively rather than innate talents and add considerably to the insights into how managers add value for their clients. They stress the importance of finding the sub-set of managers that possess these qualities. Their work builds on the contributions of Grinblatt and Titman (1993) and Daniel et al. (1997), rather than the conditional performance work of Ferson and Schadt (1996) and others, in that skill is defined as the cognitive ability to process public or private information to generate superior risk-adjusted returns. This brings us to the question whether observable skill is due to luck or the cognitive abilities noted by Kacperczyk et al. (2014).

\subsection{Skill or luck?}

In recent years, the debate has extended beyond consideration of whether funds possess skill, i.e., the ability to generate alpha a la Jensen (1968), but whether this perceived value-creating ability is due to skill or luck. This is because alpha estimates capture both skill and luck. Pioneering work in this area has been undertaken by Kosowski et al. (2006) and Barras, Scaillet, and Wermers (2010), who highlight the need for benchmarks which reflect what Aragon and Ferson (2006) call 'otherwise equivalent benchmarks', an opportunity set which is equivalent to those facing the varying types of mutual funds.

Kosowski et al. (2006) starts a strand of research in the luck vs. skill debate which is taken up by Fama and French (2010), Busse, Goyal, and Wahal (2010), and others. They apply bootstrapping techniques to evaluate if abnormal returns are the result of manager's skill or luck. They find that a 'sizeable minority' of funds create added value net of costs and the superior alphas of these funds persist. They also find, at the bottom end of the spectrum, funds that destroy value. Their study of the US mutual fund market incorporates bootstrap techniques which control for the heterogeneous risk taking among funds, the expected idiosyncratic variation in fund returns and the non-normal distribution of individual funds' alphas.

Fama and French (2010) refine the bootstrap techniques of Kosowski et al. (2006) in a study of US mutual funds. They essentially subtract a fund's estimated alpha from its return series, creating a set of returns for which the true alpha is zero for each fund. Simulated samples are then drawn from these zero-alpha fund return series. The distribution of the alphas calculated from these simulated returns is then compared to the distribution of the estimated actual alphas allowing them to 'infer' whether funds possess true skill. On average, 
they find that net of fees aggregate fund returns underperform a set of benchmarks; CAPM, three-factor, and four-factor benchmarks by approximately the amount extracted for fees. Their assessment of gross and net true alpha suggests that while there are abnormal returns in the tails of their distribution, when compared to Kosowski et al. (2006), they find less evidence of skill. They discount their more significant findings for funds compared to the CAPM model on the grounds that these are generated by the factors incorporated into the threefactor model.

Busse et al. (2010) apply the Fama and French (2010) bootstrap technique to institutional fund data and also find that for the average fund, there is no value-added performance contribution. They suggest that relative to a three-factor benchmark, there is some evidence of persistence of performance by some funds, but this is less evident when the momentum factor is added. Agyei-Ampomah, Clare, Mason, and Stephen Thomas (2015) show that the use of standard multifactor models underestimates managerial ability and overstates the proportion of funds whose abnormal performance can be attributed to chance rather than to skill, when compared with of style-consistent practitioner benchmarks. They also find that a single-factor performance evaluation model that uses Russell style indices consistent with the style orientation of a fund provides a parsimonious way of accounting for fund performance. Also contributing to the luck versus skill debate is Barras et al. (2010), who use a false discovery framework to estimate the fraction of mutual funds that truly outperform their benchmark. Skilled funds are those that add value (alpha) in excess of fees and costs. They reach an interesting conclusion that the majority of actively managed funds generate positive or zero-alpha, making them as good a choice as passive funds, but there has been a significant minority of value-destroying funds that have nevertheless managed long-term survival.

\section{Managerial characteristics and incentives}

In this section, we consider the managerial characteristics of fund managers and fund groups that undertake portfolio management via mutual funds. A function of portfolio delegation, managerial incentives, determines managerial behaviour. There seems to be three broad areas of research developing, which we feel are set to continue. The first theme is agency conflict, where tensions may exist between the managers of the fund and members of the fund board and the interests of investors. The second theme is the behaviour of fund families, i.e., those who own or control the funds. How they behave to their external clients or meet their fiduciary duties and how they operate internally, including allocation of their key asset, the fund manager. The third theme is disclosure and informational efficiency. This may result in segmentation of investors into informed and uninformed investors.

Early research into managerial aspects of mutual funds was undertaken by Khorana (1996) who looked at the turnover of top management at mutual funds and Avery and Chevalier (1999) who considered the relationship between fund manager's behaviour and fund performance. Khorana, Servaes, and Wedge (2007a) looked at the impact of manager ownership of the funds they manage and concluded that managerial ownership creates a positive incentive alignment between mutual fund managers and mutual fund investors as managerial ownership is correlated with improved performance.

\subsection{Agency conflict}

Several key papers have transported corporate governance themes into the arena of mutual fund research. As more qualitative data become available for the mutual fund industry, this type of research is likely to flourish. One such study is undertaken by Kuhnen (2009), who explores the agency conflicts between fund directors and fund management advisors, who manage the funds. She evaluates the potential of agency conflict and improved information flow where board advisor ties are strong. Her conclusion is, in the case of the US mutual fund industry, the potential for harmful collusion is balanced by improved monitoring. Extending this analysis of the role of board structure and mergers within the mutual fund industry, Khorana, Tufano, and Wedge (2007b) find that the power of independent directors plays a key role in whether a fund merger takes place. The SEC requires that $75 \%$ of fund directors are independent but where all fund directors are independent, they believe that the conflict of interest between the well-compensated target board and the shareholders of the target fund are likely to be overcome. Ferris and Yan (2007) disagree, however, as they find neither the probability of a fund scandal nor overall fund performance is related to either chair or board independence and go on to question the benefits of the SEC's actions in terms of mutual fund corporate governance.

The role of agency conflict and disclosure is investigated by Edelen, Evans, and Kadlec (2012) by considering transparency of payments for services; whether they are expensed and therefore visible or whether they are bundled with brokerage commissions and therefore opaque. The implication is that the latter is deducted directly from fund NAV, whereas the former is a cost to the fund manager or fund family. They conclude that transparency is crucial in addressing agency costs of fund management. Stoughton, Wu, and Zechner (2011) look at transparency at the entry point of funds into mutual funds. They explore the role of financial advisors and other intermediaries who often sit between investors and funds, deriving the majority of their compensation from 'kickbacks'. This links in with Guercio and Reuter's (2014) concept of informed/experienced investors and uninformed investors who are willing to pay such charges. Stoughton et al. (2011) conclude that the more competitive the market space is for active investors, the more impartial advice becomes. The theme of the 'smart' investor is also taken up by Korniotis and Kumar (2013) using a proxy for smartness (informed investors) based on demographic factors. They conclude that smart investors have informational advantages while psychological biases drive the portfolio decisions of 'dumb' investors. While this paper focuses on stocks, it is consistent with the findings of Guercio and Reuter (2014) and possibly even Stoughton et al. (2011) for funds.

\subsection{Fund families}

Berzins, Liu, and Trzcinka (2013) look at the corporate structure of fund families and offer evidence that conflicts of interest, with meaningful economic consequences, can be found where asset management businesses are owned by investment banks. This agency conflict is highlighted by comparing the effects of bank and non-bank ownership. Chen, Goldstein, and Jiang (2008) find that directors' ownership of mutual funds is more widespread than anticipated and has a beneficial effect on directors' monitoring of funds. They conclude that ownership patterns are consistent with an optimal contracting equilibrium, which adds another dimension to the agency conflict debate. Ferris and Yan (2007) considers flow of funds and agency problems finding that public fund families are more adept at raising funds than private fund families. However, other things being equal, public fund families underperform funds managed by private fund families. They conclude that because of the short-term focus of public fund management companies, the agency problem between management and shareholders is greater.

Several studies look at the way fund families treat their 'star' managers. Nohel, Wang, and Zheng (2010) found that where 'star' managers were allowed to run hedge funds alongside mutual funds, the mutual funds significantly outperformed their peer groups. This practice seems to be a means of retaining or hiring top talent. They conclude that there is no loss of welfare for mutual fund investors. Fang, Kempf, and Trapp (2014) also believe that fund families know the value of their human capital and are aware of the relationship between skill and performance. Consequently, they allocate skilled managers to less efficient markets or market segments where they can add more value and outperform less skilled or experienced managers. The role of fund 
families and monitoring is also considered by Gervais, Lynch, and Musto (2005), who investigate the relationship between fund families and their appointed fund managers. Fund families may also engage in strategic cross-subsidisation of funds, as highlighted by Gaspar, Massa, and Matos (2006). Chen, Hong, Jiang, and Kubik (2013) consider the role of outsourcing on mutual fund management. They observe that when performance and incentives are considered, it is difficult to generate abnormal returns from a manager running outsourced funds as they lie beyond the boundaries of the firm due to higher powered incentivisation and the heightened risk of withdrawal of funds. Typically, such managers underperform internal managers by a significant margin.

\subsection{Incentives}

Brown, Harlow, and Starks (1996) hypothesise that mutual fund managers have an incentive to increase their risk levels in the second half of the year if their first-half peer group ranking is very poor. This recognises the fact that while manager revenues are a function of assets under management via their fees, mutual fund flows are in part driven by peer group and benchmark performance. Schwarz (2012) uncovers new evidence of bias in sorting methods and after adjustment for these biases finds results that are consistent with increasing risktaking tournament behaviour. This behaviour seems to be driven by peer group ranking rather than first-half market conditions as represented by first-half median returns. Kempf and Ruenzi (2008) develop the mutual funds tournaments literature when they consider the role of tournaments within mutual fund families. It is well known anecdotally that all funds and fund managers are not regarded as equal within their fund families so there may be rivalry within firms which leads to tournament like behaviour. Decision taking by individual managers and the restraining elements of teams are considered by Bär, Kempf, and Ruenzi (2011) utilising the diversification of opinions and the group shift decision making theories. They find that teams have a moderating influence on each other and consequently have less extreme investment styles, less concentrated portfolios, and therefore have less extreme performance outcomes.

The role of contractual incentives with respect to mutual funds during the 'dot-com boom' was examined by Dass, Massa, and Patgiri (2008). Their conclusion was that funds with high incentives have a greater incentive not to herd and become overextended during bubbles. This can also be linked to the concept of time-varying fund manager skill as outlined by Kacperczyk et al. (2014). In practice, there may be offsetting forces in operation; while incentives may lead managers to diverge from the herd, the existence of tracking error constraints limits the ability to do so. In order to achieve the desired aim, there must be a favourable combination of both. The skilled manager must judge how far to ride the boom into the bubble and when to lock in the performance. This would be consistent with Kacperczyk et al.'s (2014) skill.

Koijen (2014) produces a dynamic model which addresses two fundamental questions: Do mutual fund managers possess skill and do managerial incentives influence risk taking? Koijen's (2014) model is applied to U.S. equity funds data and separates out managers' ability, risk preferences, and managerial incentives. The structural model embodied in the study aids fund selection via more precise estimates of manager skill, expected return per unit of additional risk, and to some degree, the time-varying beta due to variation in benchmark exposure.

The flow of funds into mutual fund categories has long been an indicator, albeit a lagging indicator, of end-user sentiment towards particular categories of funds or even into the equity market itself (see Ben-Rephael, Kandel, and Wohl, 2012). Anecdotally, it often seems that it is only possible to attract funds into a sector or style of mutual funds once that style has outperformed for a while. Frazzini and Lamont (2008) seem to share this view when they consider mutual fund flows in a study titled 'Dumb Money'. Solomon, Soltes, and Sosyura (2014) confirm this thesis and highlight the role of media coverage of mutual funds. Fund holdings with high past returns attract extra flows, but only if these stocks were recently featured in the media.

There is a wealth of information held by commercial organisations such as Morningstar and Lipper, whose raison d'etre is to collect and disseminate information on mutual funds, fund families, fund characteristics, and performance to their clients in addition to the data required by government and quasi-government bodies. As new methods of accessing and utilising these data become available, this area of research seems likely to increase.

\section{Conclusion}

When we consider the recent trends in the analysis of investment management and investment performance, one of the first things to note are the high-quality papers which have led the topic, particularly so in the newer developments and emerging trends in the area. Many of the developments in this field, going back to Fama and French $(1992,1993)$ have an empirical bias. They search for factors which can proxy securities markets and thus explain the nature and performance of investment portfolios. When we speak of realism, we mean substituting factors which proxy the investment universe and investment constraints more closely than a prior set of factors which may not have taken account of certain aspects of the nature of investment management. We should note that 23 years after their initial three-factor model, Fama and French (2015) have introduced new factors to complement and replace their earlier factors.

Our analysis of the recent literature of investment funds, investment characteristics, and investment performance leads us to conclude that the following themes are likely to drive future research: realism, skill, and incentives. These themes encompass the improvements in benchmarking which seem likely to continue to take account of the actual nature of investing with its attendant constraints. It is recognised in the literature that increasing applicability in benchmarking improves the assessment of performance. Whether this is due to skill or exogenous factors is an area of debate that can only continue to thrive. The divergence of investment behaviour suggested by investors who hold trillions of dollars in actively invested mutual fund investments and the passive allocations suggested by the traditional multifactor models must continue to be explored. The recent literature highlights some of the flaws of traditional assessments of investment opportunities and this is set to continue. Cremers et al. (2012) made a very significant contribution in this area where they observed that some benchmark indices had 'alpha', while Kosowski et al. (2006) spearheaded the new search to differentiate between skill and luck. Additionally, Kacperczyk et al. (2014) have opened up an important new area of research with their concept of time-varying fund manager skill.

The recent strides in technology are allowing quantitative and qualitative data to be more accessible. These data can be used for corporate governance purposes so the provision of these data will continue to fuel the search for appropriate managerial incentives. The theme of incentives is one area which has benefited from increasing availability of data allowing Guercio and Reuter (2014) to consider mutual funds' incentive to generate alpha or Koijen (2014) to consider ability, incentives, and risk preferences. The strategies of fund families is now open to appraisal, Gervais et al. (2005) or Fang et al. (2014), as is the role of fund directors, Ferris and Yan (2007).

While the standard academic measures of assessment, CAPM, and multifactor models, will continue to be incorporated in some future research where they can add value, it is widely recognised that the investment industry has grown exponentially since those pioneering papers were written as have the means of analysing the investment industry. It seems likely that innovative research will be focussed on the broad areas of realism, skill, and incentives as outlined above. 


\section{References}

Agyei-Ampomah, S., Clare, A., Mason, A., \& Stephen Thomas, S. (2015). On luck versus skill when performance benchmarks are style-consistent. Journal of Banking E Finance, 59(10), 127-145.

Angelidis, T., Giamouridis, D., \& Tessaromatis, N. (2013). Revisiting mutual fund performance evaluation. Journal of Banking \&' Finance, 37(5), 1759-1776.

Aragon, G.O., \& Ferson, W.E. (2006). Portfolio performance evaluation. Foundations and Trends in Finance, 2(2), 83-190.

Avery, C. N., \& Chevalier, J. A. (1999). Herding over the career. Economics Letters, 63(3), 327-333.

Baker, M., Litov, L., Wachter, J.A., \& Wurgler, J. (2010). Can mutual fund managers pick stocks? Evidence from their trades prior to earnings announcements. Journal of Financial and Quantitative Analysis, 45(5), 1111-1131.

Bali, T.G., Brown, S.J., \& Caglayan, M.O. (2014). Macroeconomic risk and hedge fund returns. Journal of Financial Economics, 114(1), 1-19.

Bär, M., Kempf, A., \& Ruenzi, S. (2011). Is a team different from the sum of its parts? Evidence from mutual fund managers. Review of Finance, 15(2), 359-396.

Barberis, N., \& Shleifer, A. (2003). Style investing. Journal of Financial Economics, 68(2), 161-199.

Barras, L., Scaillet, O., \& Wermers, R. (2010). False discoveries in mutual fund performance: Measuring luck in estimated alphas. The Journal of Finance, 65(1), 179-216.

Ben-Rephael, A., Kandel, S., \& Wohl, A. (2012). Measuring investor sentiment with mutua fund flows. Journal of Financial Economics, 104(2), 363-382.

Berk, J.B., \& Green, R.C. (2004). Mutual fund flows and performance in rational markets. Journal of Political Economy, 112(6), 1269-1295.

Berk, J.B., \& Tonks, I. (2007). Return persistence and fund flows in the worst performing mutual funds (no. w13042). National Bureau of Economic Research.

Berzins, J., Liu, C.H., \& Trzcinka, C. (2013). Asset management and investment banking. Journal of Financial Economics, 110(1), 215-231.

Brown, K.C., Harlow, W.V., \& Starks, L.T. (1996). Of tournaments and temptations: An analysis of managerial incentives in the mutual fund industry. The Journal of Finance, 51(1), 85-110.

Brown, S.J., \& Goetzmann, W.N. (1997). Mutual fund styles. Journal of Financial Economics, 43(3), 373-399.

Brown, S.J., Kang, M., In, F.H., \& Lee, G. (2010). Resisting the manipulation of performance metrics: An empirical analysis of the manipulation-proof performance measure. Finance and Corporate Governance Conference. NYU Working Paper.

Busse, J.A., Goyal, A., \& Wahal, S. (2010). Performance and persistence in institutional investment management. The Journal of Finance, 65(2), 765-790.

Carhart, M.M. (1997). On persistence in mutual fund performance. The Journal of Finance, 52(1), 57-82.

Chan, L.K., Dimmock, S.G., \& Lakonishok, J. (2009). Benchmarking money manager performance: Issues and evidence. Review of Financial Studies, 22(11), 4553-4599.

Chen, H.L., Jegadeesh, N., \& Wermers, R. (2000). The value of active mutual fund management: An examination of the stockholdings and trades of fund managers. Journal of Financial and Quantitative Analysis, 35(03), 343-368.

Chen, J., Hong, H., Jiang, W., \& Kubik, J.D. (2013). Outsourcing mutual fund management: Firm boundaries, incentives, and performance. The Journal of Finance, 68(2), 523-558.

Chen, Q., Goldstein, I., \& Jiang, W. (2008). Directors' ownership in the US mutual fund industry. The Journal of Finance, 63(6), 2629-2677.

Connor, G. (1995). The three types of factor models: A comparison of their explanatory power. Financial Analysts Journal, 51(3), 42-46.

Cremers, K.M., \& Petajisto, A. (2009). How active is your fund manager? A new measure that predicts performance. Review of Financial Studies, 22(9), 3329-3365.

Cremers, M., Petajisto, A. \& Zitzewitz, E. (2012). Should benchmark indices have alpha? Revisiting performance evaluation (no. w18050). National Bureau of Economic Research.

Cuthbertson, K., Nitzsche, D., \& O'Sullivan, N. (2010). Mutual fund performance: Measurement and Evidence1. Financial Markets, Institutions \&' Instruments, 19(2), 95-187.

Daniel, K., Grinblatt, M., Titman, S., \& Wermers, R. (1997). Measuring mutual fund performance with characteristic-based benchmarks. The Journal of Finance, 52(3), 1035-1058.

Dass, N., Massa, M., \& Patgiri, R. (2008). Mutual funds and bubbles: The surprising role of contractual incentives. Review of Financial Studies, 21(1), 51-99.

Edelen, R.M., Evans, R.B., \& Kadlec, G.B. (2012). Disclosure and agency conflict: Evidence from mutual fund commission bundling. Journal of Financial Economics, 103(2), 308-326.

Elton, E.J., Gruber, M.J., \& Blake, C.R. (2012). An examination of mutual fund timing ability using monthly holdings data. Review of Finance, 16(3), 619-645.

Fama, E.F., \& French, K.R. (1992). The cross-section of expected stock returns. The Journal of Finance, 47(2), 427-465.

Fama, E.F., \& French, K.R. (1993). Common risk factors in the returns on stocks and bonds. Journal of Financial Economics, 33(1), 3-56.

Fama, E.F., \& French, K.R. (2010). Luck versus skill in the cross-section of mutual fund returns. The Journal of Finance, 65(5), 1915-1947.

Fama, E.F., \& French, K.R. (2015). A five-factor asset pricing model. Journal of Financia Economics, 116(1), 1-22.

Fang, J., Kempf, A., \& Trapp, M. (2014). Fund manager allocation. Journal of Financia Economics, 111(3), 661-674

Farquhar, T., Rosenberg, B., \& Rudd, A. (1982). Factor-related and specific returns of common stocks: Serial correlation and market inefficiency. The Journal of Finance, 37(2), 543-554.

Farrell, J.L. (1974). Analyzing covariation of returns to determine homogeneous stock groupings. Journal of Business, 186-207.

Ferris, S.P., \& Yan, X.S. (2007). Do independent directors and chairmen matter? The role of boards of directors in mutual fund governance. Journal of Corporate Finance, 13(2), 392-420.
Ferson, W., \& Lin, J. (2014). Alpha and performance measurement: The effects of investor disagreement and heterogeneity. The Journal of Finance, 69(4), 1565-1596.

Ferson, W.E. (2013). Ruminations on investment performance measurement. European Financial Management, 19(1), 4-13.

Ferson, W.E., \& Schadt, R.W. (1996). Measuring fund strategy and performance in changing economic conditions. The Journal of Finance, 51(2), 425-461.

Fisher, P.A. (1958). Common stocks and uncommon profits. Harper \& Brothers.

Frazzini, A., \& Lamont, O.A. (2008). Dumb money: Mutual fund flows and the crosssection of stock returns. Journal of Financial Economics, 88(2), 299-322.

Gaspar, J.M., Massa, M., \& Matos, P. (2006). Favoritism in mutual fund families? Evidence on strategic cross-fund subsidization. The Journal of Finance, 61(1), 73-104.

Gervais, S., Lynch, A.W., \& Musto, D.K. (2005). Fund families as delegated monitors of money managers. Review of Financial Studies, 18(4), 1139-1169.

Glode, V. (2011). Why mutual funds "underperform”. Journal of Financial Economics, 99(3), 546-559.

Goetzmann, W.N., \& Ibbotson, R.G. (1994). Do winners repeat? Journal of Portfolio Management, 20(2), 9-18.

Goetzmann, W., Ingersoll, J., Spiegel, M., \& Welch, I. (2007). Portfolio performance manipulation and manipulation-proof performance measures. Review of Financial Studies, 20(5), 1503-1546.

Graham, B., Dodd, D.L.F., \& Cottle, S. (1934). Security analysis. New York: McGraw-Hill.

Grinblatt, M., \& Titman, S. (1992). The persistence of mutual fund performance. The Journal of Finance, 47(5), 1977-1984.

Grinblatt, M., \& Titman, S. (1993). Performance measurement without benchmarks: An examination of mutual fund returns. Journal of Business, 47-68.

Grossman, S.J., \& Stiglitz, J.E. (1980). On the impossibility of informationally efficient markets. The American Economic Review, 393-408.

Gruber, M. J. (1996). Another puzzle: The growth in actively managed mutual funds. The Journal of Finance, 51(3), 783-810.

Guercio, D.D., \& Reuter, J. (2014). Mutual fund performance and the incentive to generate alpha. The Journal of Finance, 69(4), 1673-1704.

Henriksson, R.D., \& Merton, R.C. (1981). On market timing and investment performance. II. Statistical procedures for evaluating forecasting skills. Journal of Business, 513-533.

Huij, J., \& Verbeek, M. (2009). On the use of multifactor models to evaluate mutual fund performance. Financial Management, 38(1), 75-102.

Hunter, D., Kandel, E., Kandel, S., \& Wermers, R. (2014). Mutual fund performance evaluation with active peer benchmarks. Journal of Financial Economics, 112(1), 1-29.

Investment Company Institute (2014). Investment Company Factbook.

Jensen, M.C. (1968). The performance of mutual funds in the period 1945-1964. The Journal of Finance, 23(2), 389-416.

Kacperczyk, M., Nieuwerburgh, S.V., \& Veldkamp, L. (2014). Time-varying fund manager skill. The Journal of Finance, 69(4), 1455-1484.

Kempf, A., \& Ruenzi, S. (2008). Tournaments in mutual-fund families. Review of Financial Studies, 21(2), 1013-1036.

Khorana, A. (1996). Top management turnover an empirical investigation of mutual fund managers. Journal of Financial Economics, 40(3), 403-427.

Khorana, A., Servaes, H., \& Wedge, L. (2007a). Portfolio manager ownership and fund performance. Journal of Financial Economics, 85(1), 179-204.

Khorana, A., Tufano, P., \& Wedge, L. (2007b). Board structure, mergers, and shareholder wealth: A study of the mutual fund industry. Journal of Financial Economics, 85(2), 571-598.

King, B.F. (1966). Market and industry factors in stock price behavior. Journal of Business, 139-190.

Koijen, R.S. (2014). The cross-section of managerial ability, incentives, and risk preferences. The Journal of Finance, 69(3), 1051-1098.

Korniotis, G.M \& Kumar, A. (2013). Do portfolio distortions reflect superior information or psychological biases? Journal of Financial and Quantitative Analysis, 48(01), $1-45$.

Kosowski, R., Timmermann, A., Wermers, R., \& White, H. (2006). Can mutual fund "stars" really pick stocks? New evidence from a bootstrap analysis. The Journal of Finance, 61(6), 2551-2595.

Kothari, S.P., \& Warner, J.B. (2001). Evaluating mutual fund performance. The Journal of Finance, 56(5), 1985-2010.

Kuhnen, C.M. (2009). Business networks, corporate governance, and contracting in the mutual fund industry. The Journal of Finance, 64(5), 2185-2220.

Mason, A. (2013). Equity investment styles. In H.K. Baker, \& G. Filbeck (Eds.), Portfolio theory and management. Oxford University Press.

Menzly, L., \& Ozbas, O. (2010). Market segmentation and cross-predictability of returns. The Journal of Finance, 65(4), 1555-1580.

Nohel, T. Wang, Z.J., \& Zheng. L. (2010). Side-by-side management of hedge funds and mutual funds. Review of Financial Studies, 23(6), 2342-2373.

Schultz, P. (2010). Rational cross-sectional differences in market efficiency: Evidence from mutual fund returns. Journal of Financial and Quantitative Analysis, 45(4), 847-881.

Schwarz, C.G. (2012). Mutual fund tournaments: The sorting bias and new evidence. Review of Financial Studies, 25(3), 913-936.

Sensoy, B.A. (2009). Performance evaluation and self-designated benchmark indexes in the mutual fund industry. Journal of Financial Economics, 92(1), 25-39.

Sharpe, W.F. (1964). Capital asset prices: A theory of market equilibrium under conditions of risk. The Journal of Finance, 19(3), 425-442.

Sharpe, W.F. (1967). Portfolio analysis. Journal of Financial and Quantitative Analysis, 2(02), 76-84

Sharpe, W.F. (1992). Asset allocation: Management style and performance measurement. Journal of Portfolio Management, 18(2), 7-19.

Sialm, C., \& Starks, L. (2012). Mutual fund tax clienteles. The Journal of Finance, 67(4), 1397-1422. 
Sialm, C., Starks, L.T., \& Zhang, H. (2015). Defined contribution pension plans: Sticky or discerning money? The Journal of Finance, 70(2), 805-838.

Solomon, D.H., Soltes, E., \& Sosyura, D. (2014). Winners in the spotlight: Media coverage of fund holdings as a driver of flows. Journal of Financial Economics, 113(1), 53-72.

Stivers, C., \& Sun, L. (2010). Cross-sectional return dispersion and time variation in value and momentum premiums. Journal of Financial and Quantitative Analysis, 45(4), $987-1014$.

Stoughton, N.M., Wu, Y., \& Zechner, J. (2011). Intermediated investment management. The Journal of Finance, 66(3), 947-980.
Treynor, J., \& Mazuy, K. (1966). Can mutual funds outguess the market? Harvard Business Review, 44(4), 131-136.

Wagner, N., \& Winter, E. (2013). A new family of equity style indices and mutual fund performance: Do liquidity and idiosyncratic risk matter? Journal of Empirical Finance, 21, 69-85.

Wahal, S., \& Yavuz, M.D. (2013). Style investing, comovement and return predictability. Journal of Financial Economics, 107(1), 136-154. 